Љиљана Н. Башић

Прегледни рад

Народна библиотека Србије,

UDK 027.7:[378.6:271.222(497.11)

Београд

027.7:021.7

ljiljana.basic@nb.rs

https://doi.org/10.18485/bibliotekar.2021.63.1.4

Маја М. Аћимовић

Универзитет у Београду,

Православни богословски факултет

macimovic@bfspc.bg.ac.rs

\title{
ЗНАЧАЈ ЛЕГАТА И БИБЛИОТЕКА ЦЕЛИНА НА ПРАВОСЛАВНОМ БОГОСЛОВСКОМ ФАКУЛТЕТУ И ПРОБЛЕМИ ЊИХОВОГ ЕВИДЕНТИРАҢА
}

\begin{abstract}
Сажетак: Рад је настао као резултат истраживања и систематског евидентирања легата и библиотека целина на Православном богословском факултету Универзитета у Београду. Имајући у виду да је легаторство на Православном богословском факултету старо колико и његова Библиотека - један век (1920-2020), било је неопходно истражити архивску грађу и представити стечена сазнања о овим збиркама. Професорски досијеи и записници који су вођени током седница Савета факултета, а који су сачувани у Архиви Православног богословског факултета (АПБФ), разговори вођени са сведоком из времена преузимања појединих збирки, непроцењив су извор података о дародавцима, њиховим библиотекама и начину њиховог поклањања Факултету. Како је поменуто, поред настојања да се јавности представе стечена сазнања и искуства током истраживања збирки, намера је и да се јавност упозна са већ учињеним, али и са плановима у вези са представљањем садржаја личних библиотека и њихових вредности.
\end{abstract}

Кључне речи: легати, библиотеке целине, Архива Православног богословског факултета, класификација

Када говоримо о легатима, обично на уму имамо специфичну материјалну заоставштину људи који су радом и животом обележили време у којем су живели. Било да је реч о књигама, документима, уметничким 
делима или некој другој врсти заоставштине, легат је увек веза између интелектуалног наслеђа и савременика. Легати су преносници културног наслеђа, извор дубљих сазнања, духовна веза међу поколењима и пре свега отелотворење хуманистичких и просветитељских идеала. Са једне стране, они су чувари националне културе, традиције и идентитета, а са друге представљају везу са универзалним културним, научним, политичким и другим наслеђем из којег преиспитујемо и настојимо да разумемо и прошлост и савремене прилике, али и себе и друштво у простору и времену.

Легаторство јесте посебан вид доброчинства и даривања које поред материјалне оставштине садржи невидљиве дарове који надахњују и инспиришу поколења. Међутим, биће и оних који ће рећи да су легати првенствено израз жеље дародавца да очува сећање на себе, блиске људе, своје дело и идеје, и малициозно ће покушати да им одузму хуманистичку перспективу. Не занемарујући људску природу, која може бити и егоистичка и нарцисоидна, чини се да са прилично сигурности можемо тврдити да су легати сами по себи негација таквих сентимената. Они чувају и преносе вредности, њихови савезници су врлина, истина и време, а у њиховој сржи најчешће јесте чин даривања.

Библиотека Православног богословског факултета Универзитета у Београду у почетку се развијала захваљујући поклонима, новчаним прилозима, посебним фондовима основаним за помоћ и развој библиотеке, попут чувеног Фонда мис Џенкинс, чијим су средствима набављана ретка издања из иностранства, као и Фонда Луке Ћеловића Требињца. ${ }^{1}$ За развој библиотечког фонда заслужни су и појединци који су даривали велики број својих књига попут првог декана Стеве Димитријевића, Милана Мратинковића, проте Милојевића, Благоте Гардашевића и других. Међутим, највеће богатство библиотеци оставили су професори Богословског факултета, почевши од академика Драгутина Анастасијевића, професора Јордана Илића, Лазара Мирковића, Душана Глумца, Милоша Ердељана и других.

Институција легата, то јест даривања зарад јавног добра, без сумње је била подстицај оснивању или развоју многих националних културних и научних институција. У многима од њих се поред изворних дариваних збирки чувају и друге, дуго скриване од јавности, али се њихов културни и научни значај ревитализује захваљујући савременим технологијама и електронским комуникацијама. У том контексту легати постају јасна

\footnotetext{
Милић Ф. Петровић, „Фондови завештања Православног богословског факултета у Београ-

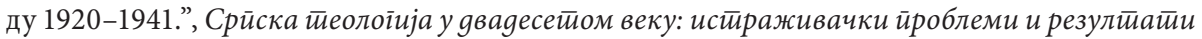
1 (2007): 218.
} 
материјална линија идентитетског, духовног и културног континуитета и снажан печат историјских и савремених интеракција националне културе и науке са светом. Међу тим завештањима велики је број оних који нас враћају или подсећају на универзалне и националне вредности и идентитет, или су инспирација и извориште савремених промишљања о парадигмама, теоријама, историјским истинама и заблудама, култури и уметности.

Богате збирке које су Православном богословском факултету већином оставили бивши професори овог факултета чувају се као засебне целине, смештене на покретним полицама, у издвојеном делу депоа зграде Факултета. Имајући у виду њихов значај, настојало се да се систематски евидентирају и анализирају како би се налази представили јавности и учинили видљивим.

Трагајући за информацијама о збиркама, дошло се до сазнања да се о њима спорадично писало у литератури, али не као о јасно дефинисаним целинама већ у оквиру биографских података легатора поводом обележавања различитих јубилеја (обележавање годишњице рада, упокојења). Те текстове су писале колеге, научни радници са Православног богословског факултета и други који су селективно наводили податке о библиотекама које су као целине поклањане Факултету.

Чињенице да су ове библиотеке биле у власништву личности које су уживале поштовање и признање у различитим областима науке и културе и да су још приликом пријема категорисане као вредне целине, које су чуване као такве, указују на испуњеност услова да им се призна правни статус легата или библиотеке целине.

Утврђено је да су све личне библиотеке поклоњене, да ниједна није набављена куповином. Из тог разлога, приликом категорисања ових збирки као легата или библиотека целина, било је неопходно и да се детаљније уреди њихов правни статус. При том требало је водити рачуна да статус обеју категорија, тестаментарно завештање Факултету и поклон власника библиотеке или лица која су их наслеђивала, произлази из института даривања.

Основни изазов био је проналажење извора података у литератури о пристизању личних библиотека на Факултет. Проблем се појавио у виду помањкања докумената упркос томе што су постојале јасне информације у литератури о њиховом постојању. Важно је поменути да већина оригиналних докумената није сачувана, али да се до њихових садржаја дошло 
посредно, користећи доступне изворе из Архиве Православног богословског факултета. Разлози осиромашења фонда су различити, али свакако да су то и честе селидбе Факултета све до 1995. године, када је смештен у садашњи простор. Током Другог светског рата, Библиотека и Архива Факултета су сачувани захваљујући митрополиту скопском Јосифу (Цвијовић), који је тада био на челу Српске цркве, који их је благовремено, 1943. године, изместио из зграде у Улици краља Петра, у којој је Факултет радио од 1932. године, у зграду Патријаршије. ${ }^{2}$ Захваљујући томе у Архиви су сачувани документи са драгоценим подацима који су омогућили увид у рад установе тог времена.

На Факултету су вођени записници, службене белешке о свим важним догађајима, о донетим одлукама везаним за рад Факултета, наставу, за начин набавке неопходне литературе за потребе студија, обавезама појединих професора да набаве стручну литературу за библиотеку приликом службеног боравка у иностранству. Поклони дародаваца су такође били важан чин достојан евидентирања у записнику. Како се показало, ови записници су вођени концизно, са детаљним информацијама, писани читљиво, пенкалом, у прегледним ступцима, са назначеним датумом седница, што је отварало могућност истраживања на основу расположивих података о начину и годинама поклањања личних библиотека. У сваком од записника навођена су имена присутних професора, што их, можемо слободно рећи, чини сведоцима веродостојности свих података који се могу наћи у њима.

На овај начин из Записника сазнајемо да је редован професор др Драгутин Анастасијевић (1877-1950) изјавио на седници Савета да своју библиотеку, која је већ у просторијама Факултета, поклања Богословском факултету и том приликом је поднео представку чији је садржај у целости наведен у Записнику. Писана представка није сачувана у оригиналу, тако да је текст у Записнику једини траг његовог завештања. Савет је са радошћу и одушевљењем примио богат дар и истовремено решио да се за ову библиотеку изради засебна картотека и да ова библиотека и даље буде

2 Љиљана Башић и Маја Аћимовић, „Легати и библиотеке целине у Библиотеци Православног богословског факултета Универзитета у Београду”, у Посебне збирке у кониеексйу

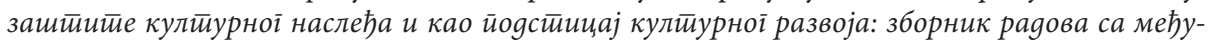
нарояне конферениије Оgетень йосебних фондова Народне библиоиеке Србије, Беоіраg, 2-4. окӣобар 2017, ур. Маша Милорадовић и Дејан Вукићевић (Београд: Народна библиотека Србије, 2019), 470. 
смештена у засебној просторији. ${ }^{3}$ На основу Записника сазнајемо и да је универзитетски професор др Душан Глумац (1899-1980) поклонио своју библиотеку и да је послао Факултету тестаментарно писмо, које је у целости наведено у Записнику. ${ }^{4}$

Такође, из Записника добијамо информације да је протојереј Живан Маринковић (1899-1976), ректор Богословије у пензији, 1956. године намеравао да своју личну библиотеку поклони Богословском факултету и да је ово сазнање Савет примио са захвалношћу и решио да му написмено захвали на његовој одлуци. ${ }^{5}$ Постојање ове збирке као засебне целине у Библиотеци Факултета, потврђује да је ову намеру испунио. Исте године, налазимо да је професор др Лазар Мирковић (1885-1968) изјавио „да је написао тестамент, према коме своју библиотеку оставља факултету”. ${ }^{6}$ Али имамо и пример да је 1960. године Живка Р. Јосић, супруга покојног Радивоја Јосића, писмом обавестила декана Богословског факултета о жељи свог супруга Радивоја Јосића да своју библиотеку остави Факултету. „Знајући свагдашњу љубав и сагоревање мог покојног мужа за тај факултет на коме је провео и радио скоро цео свој живот желим да извршим његов аманет и овим писмом изјављујем да ћу све његове књиге по његовој жељи предати на поклон Савету Богословског факултета, да се сместе на факултету како би послужиле на корист наставницима и студентима а нарочито оним који наставе проучавати предмет који је мој покојни муж предавао.”7 Овај податак о даривању, пронађен је у Професорском досијеу Радивоја Јосића. Досијеи који се чувају у Архиви Факултета показали су ce, уз записнике, као значајни додатни извори информација о легатима.

На основу записника, у деловима који се односе на даривање личних библиотека, као и професорских досијеа, који се чувају у Архиви Факултета осим података који су нам „открили” на који начин је библиотека

3 Архива Православног богословског факултета (АПБФ), Записник, књ.V (1948-1953), „Записник бр. 14 седнице Савета богословског факултета одржане 2. фебруара 1948. године, члан 101".

4 АПБФ, Записник, књ. VIII (1967-1981), „Записник седнице Савета Православног богословског факултета одржане 23. јануара 1976. године, члан 9".

5 АПБФ, Записник, књ. VI (1953-1958), „Записник седнице Савета богословског факултета одржане 1. септембра 1956. године, 6р. 8”.

6 АПБФ, Записник, књ. VI (1953-1958), „Записник седнице Савета богословског факултета Српске православне цркве одржане 13. октобра 1956. године, бр. 17”.

7 АПБФ, Професорски досије Радивоја Јосића, „Писмо декану Богословског факултета, Живка Р. Јосић”, Београд, 20. 8. 1960. године. 
остављена Факултету, добијени су и подаци о библиотекама и њиховим дародавцима, као и о разлозима доношења таквих одлука, али и о начину поступања Факултета на основу тих одлука. На комеморативној седници Савета Богословског факултета, поводом смрти др Јордана П. Илића (1883-1950) који је преминуо после краћег боловања, долазимо до сазнања да се на предлог др Душана Глумца и др Чедомира Драшковића „почивши Јордан П. Илић, који је још за живота поклонио факултету своју библиотеку, прогласи за великог добротвора Православног богословског факултета и да се упише као добротвор Храма Св. Саве у Београду”. ${ }^{8}$ Како је током читавог професорског рада бринуо о сиромашним студентима, Савет је донео одлуку да уместо куповине венаца и цвећа новац поклони материјално најсиромашнијем студенту.

Захваљујући до сада наведеним подацима, дошло се до закључка да су у питању легати које су дародавци тестаментарно завештали Факултету. ${ }^{9}$

На основу записника и професорских досијеа добијају се и подаци о даривању личних библиотека др Милоша Ердељана (1907-1976), ${ }^{10}$ др Сергија Троицког (1878-1972), ${ }^{11}$ Драгића Пешића. ${ }^{12}$ Породица, то јест син покојног професора Ердељана, поклонио је његове књиге и ствари Факултету. Ова библиотека је категорисана као библиотека целина јер је поклоњена од стране лица које ју је наследило. Тако је категорисана и библиотека др Сергија Троицког, а на основу писма Јелисавете, супруге професора Троицког, које је послала Факултету и које је прочитано на седници Савета. У писму је изразила жељу да Факултету поклони књиге покојног супруга на дан Светог Саве, односно 27. јануара 1977. године. ${ }^{13}$ Библиотека Драгића Пешића, такође је поклоњена Факултету, и сврстана је у библиотеке целине, при чему се из Записника сазнаје и то да

8 АПБФ, Записник, књ.V (1948-1953), „Записник бр. 43 седнице Савета богословског факултета одржане 2. децембра 1950. године, тачка 1".

9 Овом приликом захваљујемо колеги Велибору Прелићу, водитељу Збирке библиотека целина и легата у Одељењу посебних фондова на помоћи приликом утврђивања валидности докумената о даривању личних библиотека.

10 АПБФ, Записник, књ.VIII (1967-1981), „Записник седнице Савета богословског факултета Српске православне цркве одржане 4. септембра 1976. године”.

11 АПБФ, Записник, књ. VIII (1967-1981), „Записник бр. 43 седнице Савета богословског факултета одржане 8. октобра 1977. године, тачка 1”.

12 АПБФ, Записник, књ. IX (1982-1991), „Записник седнице Савета богословског факултета Српске православне цркве одржане 8. јуна 1982. године”. О професору Драгићу Пешићу нису пронађени додатни подаци ван оних у Записнику.

13 АПБФ, Професорски досије Сергија Троицког, „Господину декану Богословског факултета, Јелисавета Троицки”, Београд, 24. 1. 1977. године. 
библиотека садржи 650 књига и часописа, и да је заједно са извесним намештајем већ пренета у зграду. ${ }^{14}$

Још један извор информација током истраживања личних библиотека био је и разговор са Жарком Шарчевићем, данас библиотекаром у пензији, који је учествовао у преузимању библиотеке др Димитрија Димитријевића. Том приликом утврдило се да је Радивој Димитријевић поклонио део очеве библиотеке. Након анализе, у овом случају категорисане библиотеке целине, уочено је да библиотека садржи осим публикација др Димитрија Димитријевића и публикације његовог сина, а на основу печата који се налазио на њима: Радивој Д. Димитријевић-грађевински инспектор.

Током истраживања стекао се утисак да су дародавци, било да су у питању власници или њихови наследници, са поносом и дубоким уважавањем поклањали библиотеке Православном богословском факултету.

Занимљиво је да је током истраживања и рада на категоризацији личних библиотека, на Факултет дошао докторанд Н. Андријашевић из Минхена, који је проучавао живот и рад др Ђоке Слијепчевића (1907-1993). Намера му је била да проучи и његов легат. Током разговора дошло се до сазнања да поседује документ којим је Слијепчевић завештао личну библиотеку Православном богословском факултету. На основу тога закључено је да се тај документ налази и у Професорском досијеу Ђоке Слијепчевића. Реч је о писму које је из Келна декану Богословског факултета послала Љеља Слијепчевић 17. маја 2002. године, у коме наводи: „Имам изузетну част и задовољство да испуним једну од последњих жеља мога покојног оца, Професора Др Ђоке Слијепчевића, из Келна, да Богословском факултету Српске православне цркве, преко овлашћених пуномоћника предам његов легат-целокупну библиотеку, која заједно са часописима, износи око 2.900-3.000 примерака, укључујући и његова ауторска дела." ${ }^{15}$ Ово писмо је потврда да је у питању тестаментарно завештање др Ђоке Слијепчевића.

Током истраживања наилазило се на фрагментарне извештаје о постојању још неких личних библиотека, али се ни на основу њих није могло утврдити у којем броју и које публикације припадају одређеном легатору. Тако је у Записнику пронађено да: „Декан саопштава да је судском одлуком констатовано да је тестамент проте М. Милојевића, у коме

14 АПБФ, Записник, књ. IX (1982-1991), „Записник седнице Савета богословског факултета Српске православне цркве одржане 8. јуна 1982. године”.

15 АПБФ, Професорски досије Ђоке Слијепчевића, „Декану Богословског факултета Српске православне цркве, Београд”, др Љеља Слијепчевић, Келн 17. 5. 2002. године. 
је завештао факултету своју библиотеку, пуноважан." ${ }^{16}$ Иако информација о садржају документа постоји, није се могло утврдити које публикације припадају овој библиотеци због непостојања засебних инвентарних књига на основу којих би се одредила припадност публикација. То је разлог због чега су многобројне публикације утопљене у општи фонд, па се у њему могу наћи и примерци са печатима или посветама одрећеним легаторима.

Морамо имати у виду то да су на почетку рада Факултета поклоњене збирке биле стожер стварања почетног фонда Библиотеке, али да оне нису биле завођене у засебне књиге инвентара. Касније, у време пристизања легата била је пракса да особље ангажовано за рад у Библиотеци (најчешће су то били библиотекари) попише комплетан легат у засебну инвентарну књигу. Потом се израђивао лисни ауторски каталог, који се и данас налази у Библиотеци. Први већи легат који је пописан на иницијативу Савета факултета је легат Драгутина Анастасијевића. Након тога, ово је постала пракса захваљујући којој имамо увид у фонд личних библиотека које се чувају на Православном богословском факултету.

У електронском каталогу ${ }^{17}$ налазе се записи публикација из неколико легата и библиотека целина. Све публикације каталошки су обрађене према стандардима који се примењују за обраду монографских публикација (ISBN-M), док је периодика пописана у ексел фајлу. Тада су ревидирани легати и библиотеке целине, након чега је установљено да су се током времена и уз повремене селидбе, одређени наслови загубили. Разлог зашто све збирке још нису уведене у електронски каталог је помањкање библиотечког кадра.

Након брижљивог систематског рада и категорисања библиотека, изведен је закључак да Православни богословски факултет у свом фонду данас има тринаест библиотека целина и легата, које чува као засебне целине. Осам од њих има статус легата: академика др Драгутина Анастасијевића, др Ђоке Слијепчевића, др Јордана Илића, др Душана Глумца, др Лазара Мирковића, др Радивоја Јосића, Живана Маринковића и Велимира хаџи Арсића, а пет су библиотеке целине: др Милоша Ердељана, др Сергија Троицког, др Димитрија Димитријевића, др Радмила Вучића и Драгића Пешића.

О легатима и библиотекама целинама први пут је писано у раду за конференцију „Посебне збирке у контексту заштите културног наслеђа и

\footnotetext{
16 АПБФ, Записник, књ.V (1948-1953), „Записникседнице Савета богословског факултета одржане 2. децембра 1948. године, чл. 13”.

17 http://biblioteka.etf.rs/
} 
као подстицај културног развоја". 18 Том приликом описан је њихов садржај, ретка издања која похрањују и друге информације. Намера је да се у овом раду скрене пажња на материјалну вредност ових библиотека и то у контексту индивидуалних напора дародаваца да их формирају, потом и да се поделе сазнања о библиотекама на основу утврђених налаза. Ништа мања није амбиција да се укаже на начин чувања и промоције ових збирки на Факултету које и данас имају употребну вредност, као и о томе шта је урађено од времена када је истраживање обављено па до данас.

Многе публикације у овим библиотекама су библиографски непроцењиве, али мора се имати на уму и то да им припада и одређена материјална вредност јер су нарочито стручна дела, још у време првих издања, била скупа и тешко доступна. Податак из тестаментарног писма др Душана Глумца говори нам и о материјалној, новчаној вредности његове библиотеке у то време: „...изјављујем да драговољно поклањам своју велику библиотеку која би данас вредела преко 30 милиона динара...”. ${ }^{19}$ Ово показује колико је жеље, али и одрицања морало бити, нарочито код оних слабог имовинског стања да би дошли у посед књига. Тако се зна да је др Јордан Илић по завршеном факултету, осам година штедео радећи као учитељ по селима зарад одласка на постдипломске студије у Швајцарску. Након успешно завршених докторских студија вратио се у Србију са већ оформљеном богатом стручном библиотеком на немачком језику, коју је још током академског рада на Факултету увећавао, а потом поклонио Православном богословском факултету. Подаци у овом примеру указују нам на поднету жртву у оскудним материјалним условима, праћеним и болешћу, зарад добављања књига, али посредно нас упућују и на садржај легата и на разлог што у њему преовлађују књиге на немачком језику. Ове библиотеке су сведоци живљења, упорности, љубави према науци, знању, књигама и не смемо их схватити као збир пуких штампаних дела, јер оне су пример прегалаштва на којем почивају наша наука и култура.

Иако се о легату Драгутина Анастасијевића (1877-1950) често говорило, што је донекле и разумљиво, имајући у виду да је Анастасијевић један од утемељивача византологије код нас, оно што би требало поновити и што завређује посебну пажњу јесте да је Атанасијевић остао упамћен и по томе што је након уништења тешко и дуго формиране Семинарске, али и личне библиотеке током балканских ратова и Првог светског рата, успео поново

\footnotetext{
Башић и Аћимовић, „Легати и библиотеке целине...”, 467-483.

19 АПБФ, Записник, књ. VIII (1967-1981), „Записник седнице Савета Православног богословског факултета одржане 23. јануара 1976. године, члан 9".
} 
да их обнови. ${ }^{20}$ У периоду од 1920. до 1948. године који обележавају немаштина и отежани услови за живот и рад, успео је да оформи вредну, стручну библиотеку од 2.600 наслова. Захваљујући томе овај легат је највреднији и најбројнији на Православном богословском факултету.

Чињеница је да велики број значајних публикација из легата и библиотека целина и данас користе студенти, професори, научници, истраживачи. Управо тај моменат, да су и даље драгоцено извориште знања, додатно им увећава вредност. Ове библиотеке нису тек пуки споменици сећања већ живи извори.

Неретко се дешавало да су корисници упућени на публикације садржане у легатима, посебно у легатима Драгутина Анастасијевића, Лазара Мирковића, Душана Глумца... Ова потреба за публикацијама из легата нужно је захтевала доношење одређених правила о поступању са грађом из легата ради њихове заштите. Како није постојао правилник о коришћењу грађе из ових збирки, дошло се до закључка о његовој неопходности. Истраживање легата потакло је детаљну израду правилника, што је и реализовано доношењем Правилника Библиотеке Православноі боіословскоі

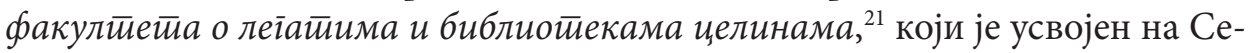
дници Наставно-научног већа, 15. маја 2017. године (бр. одлуке 01/4-343/9). Чланом Правилника утврђени су услови по којима се публикације из тих збирки користе искључиво у просторијама читаонице Библиотеке и уз надзор библиотекара.

Са друге стране, неминовно се долази до закључка да би најчешће коришћене публикације требало дигитализовати ради њихове лакше доступности и физичког очувања. Отуда је и проистекла идеја да се оствари сарадња са Српском академијом наука и уметности у виду заједничког пројекта Православног богословског факултета и Византолошког института на дигитализацији комплетног легата Драгутина Анастасијевића. Ово би уједно био и пример добре праксе међуинституционалне сарадње.

Личне библиотеке чувају се у „матичној” институцији јер је већина дародаваца поникла из Православног богословског факултета или су били запослени на Факултету. Отуда су и публикације у легатима блиске потребама и интересовањима оних који на њему раде, студирају, истражују... Процена и рангирање њихове вредности тиме је олакшана, било да је у

Башић и Аћимовић, „Легати и библиотеке целине...”, 473.

21 Маја М. Аћимовић, једна од ауторки, дипломирани библиотекар, запослена на Православном богословском факултету, израдила је Правилник Библиотеке Православної боїослов-

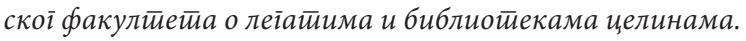


питању њихова материјална или научна вредност будући да су њихови корисници специјализовани стручњаци. Важно је напоменути, иако то не улази у делокруг научног знања, да поједини ретки примерци који су део легата који се чувају на Православном богословском факултету достижу и материјалну вредност као дигитализовани примерци издавачких компанија.

У циљу промовисања легата и библиотека целина, намера је да се штампају појединачне монографије за сваку збирку у оквиру едиције

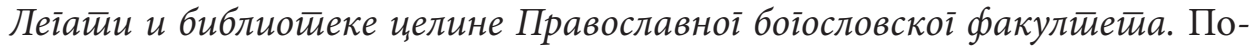

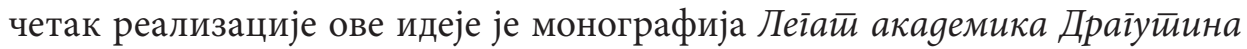
Анасйасијевићa, ${ }^{22}$ која је у штампи. Поред биографских података о легатору, монографија садржи и библиографију Драгутина Анастасијевића, биобиблиографију, као и каталог публикација садржаних у легату.

Још један начин промовисања ових збирки јесу изложбе о легатима и њиховим дародавцима. Остварењу ове идеје допринело је приређивање изложбе „Заоставштина за будућност - Легат Драгутина Анастасијевића”, која је пропраћена каталогом под истим називом, ${ }^{23}$ а поводом стогодишњице Православног богословског факултета.

Легати и библиотеке целине немо сведоче о упорности и истрајности њихових власника, како у животу, тако и у раду. Њихови садржаји су сведочанство прегалаштва дародаваца, њихове посвећености универзалним и националним циљевима, а поколењима шаљу поуку да све што вреди иза себе носи бреме огромног труда и рада. Они су темељи који нас надахњују да стремимо ка вишем.

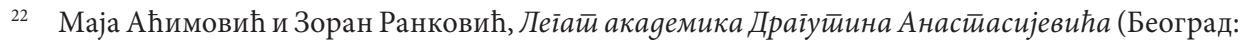
Православни богословски факултет, 2021). (у штампи)

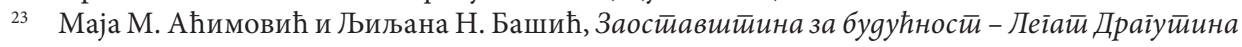
Анасйасијевића (Београд: Православни богословски факултет, 2021). 


\section{Literatura i izvori:}

1. Arhiva Pravoslavnog bogoslovskog fakulteta (APBF), Profesorski dosije Radivoja Josića. (na ćirilici)

2. Arhiva Pravoslavnog bogoslovskog fakulteta (APBF), Profesorski dosije Đoke Slijepčevića. (na ćirilici)

3. Arhiva Pravoslavnog bogoslovskog fakulteta (APBF), Profesorski dosije Sergija Troickog. (na ćirilici)

4. Arhiva Pravoslavnog bogoslovskog fakulteta (APBF), Zapisnik, knj. V (1948-1953). (na ćirilici)

5. Arhiva Pravoslavnog bogoslovskog fakulteta (APBF), Zapisnik, knj. VI (1953-1958). (na ćirilici)

6. Arhiva Pravoslavnog bogoslovskog fakulteta (APBF), Zapisnik, knj. VIII (19671981).(na ćirilici)

7. Arhiva Pravoslavnog bogoslovskog fakulteta (APBF), Zapisnik, knj. IX (1981-1982). (na ćirilici)

8. Aćimović, Maja i Zoran Ranković. Legat akademika Dragutina Anastasijevića. Beograd: Pravoslavni bogoslovski fakultet, 2020. (na ćirilici)

9. Aćimović, Maja i Ljiljana Bašić. Zaostavština za budućnost - Legat Dragutina Anastasijevića. Beograd: Pravoslavni bogoslovski fakultet, 2021. (na ćirilici)

10. Bašić, Ljiljana i Maja Aćimović. „Legati i biblioteke celine u Biblioteci Pravoslavnog bogoslovskog fakulteta Univerziteta u Beogradu." U Posebne zbirke u kontekstu zaštite kulturnog nasleđa $i$ kao podsticaj kulturnog razvoja: zbornik radova sa međunarodne konferencije Odeljenja posebnih fondova Narodne biblioteke Srbije, Beograd, 2-4. oktobar 2017, urednici Maša Miloradović i Dejan Vukićević, 467-483. Beograd: Narodna biblioteka Srbije, 2019. (na ćirilici)

11. Petrović, Milić F. „Fondovi zaveštanja Pravoslavnog bogoslovskog fakulteta u Beogradu 1920-1941." Srpska teologija u dvadesetom veku: istraživački problemi $i$ rezultati 1 (2007): 207-220. (na ćirilici) 


\title{
Ljiljana N. Bašić
}

National Library of Serbia, Belgrade

ljiljana.basic@nb.rs

\section{Maja M. Aćimović}

University of Belgrade, Faculty of Orthodox Theology

macimovic@bfspc.bg.ac.rs

\section{SIGNIFICANCE OF LEGACIES AND LIBRARY COLLECTIONS AT THE FACULTY OF ORTHODOX THEOLOGY AND PROBLEMS OF THEIR CLASSIFICATION}

\begin{abstract}
Summary: This paper is a result of research and systematic recording of legacies and library collections at the Faculty of Orthodox Theology of the University of Belgrade. Bearing in mind that the legislature of the Faculty of Orthodox Theology is one century old, like its Library (1920-2020), it was necessary to research the archival material and present the acquired knowledge about these collections. Teaching dossiers, minutes kept during the Faculty Council meetings kept in the archives of the Faculty of Orthodox Theology (APBF), and conversations with the witness from the time of taking over certain collections, are all invaluable sources of information about donors, their libraries, and the way they donate them to the Faculty. As already mentioned, in addition to the authors' efforts to present the knowledge and experiences gained during the research of the collections, their intention is also to show what has already been done and what are the plans regarding the presentation of the content of personal libraries and their values.
\end{abstract}

Keywords: archive, Faculty of Orthodox Theology, legacy, library collection, classification.

Примљено: 5. априла 2021. Прихваћено: 4. јуна 2021. 